\title{
Social Realist Ontology for Analysing BRICS Educational Governance: A Higher Education Perspective
}

Oscar Oliver Eybers ${ }^{\dagger}$

\section{Abstract}

This study advocates a social realist ontological framework as an effective, analytical blueprint for identifying problems and solutions in BRICS, educational governance systems; specifically as related to the higher education domain. The methods of the study include a textual analysis and description of a social realist ontology to illustrate how it may be applied towards mapping human experiences, including our undergoing processes of educational governance and their tangible outcomes in society. The study also highlights media and scholarly texts from BRICS nations to illustrate shared, yet contextually diverse educational challenges in the tertiary system. The value of comparing contemporary BRICS-related educational challenges, within a social realist ontology, is that it was possible to identify similar and diverging mechanisms which BRICS nations applied towards solving them. The results of the study indicate that a social realist ontology is also an applicable methodology for comparing challenges in the higher education sector and diverse educational governance responses to them by BRICS nations. The study highlights that in each nation, social structures including statutory bodies, culture, including those of citizens, as well as agency, including administrators and students, equally impacts on the efficacy of educational governance and its goals. The study concludes that by highlighting the powers of culture, social structures and agency in BRICS nation's educational governance processes, member states may effectively direct necessary human, social and financial capital where they are needed in educational systems. Further, it was found that a social realist ontology enables BRICS nation-states to compare best practices of educational governance in the higher education sphere in order to learn from each other.

Keywords: Social Realism; Ontology; Higher Educational Governance; BRICS

\footnotetext{
' Lecturer, Unit for Academic Literacy, University of Pretoria, South Africa, Email: oscar.eybers@up.ac.za (c) 2020 Eybers. This is an Open Access article distributed under the terms of the Creative Commons Attribution License (http://creativecommons.org/licenses/by/2.0), which permits unrestricted use, distribution, and reproduction in any medium, provided the original work is properly cited.
} 


\section{Introduction}

BRICS was created as a geopolitical formation in 2009 to develop further the people and socioeconomic domains of those nations (Nayyar, 2016). Originally these states included Brazil, Russia, India and China. South Africa is the newest entity to join the collective (Besudo, Tok, \& Winters, 2013). Scholars from disciplines as diverse as political science, economics and cultural studies are intrigued by BRICS's structural formation partially due to its diverse historical origins and steady emergence into the global economy as an active agent (Lo, Hiscock, \& Edward Elgar, 2014; Vadra, 2017; van Noort, 2018). The national histories of each nation and how these histories have intertwined with the development of the rest of the global community is significant to the context of this study. This is because a nation's modes of educational governance emerge from its past epistemic traditions. As a concept educational governance denotes "instruments and modes, procedures and actors" (Amos, 2010, p. 1) in the higher education domain. These are policies, mechanisms and the people who develop and employ them. Of equal significance to this study is the notion of 'governmentality' (Amos, 2010, p.1). Foucault's (2004, p.3) approach towards governmentality frames it as those principles and ideologies which motivate how key actors distribute resources for purposes of implementing its policies throughout society. The concept governmentality aids scholarly attempts to highlight "different subjectivities" (Amos, 2010, p. 1) which are active in the ways powerful agents implement policies in the higher education sector. Governance of higher education systems, in Amos's (2010) perspective, incorporates those subjectivities or the agency which BRICS agents bring to critical decision-making events and policy formulation. In the social realist, ontological framework (Archer, 1995) of this study, these actors include policymakers, managers, academics and students in the higher education system. How these actors apply their governmentality in overseeing higher education systems is shaped by geopolitical, historical, economic and cultural factors.

Each BRICS nation possesses its unique governance and governmentality challenges related to the higher education sector. To recall, governmentality involves the interplay between the cultures and ideologies of BRICS members and how these are active in shaping policy (Amos, 2010). Such challenges are, in turn, shaped by geographical regions as well as the living conditions, hopes and aspirations of BRICS inhabitants. Indeed, the BRICS collective is mandated to strategically foster interrelationships among its members in a manner which enhances the economic wellbeing of their populaces. Historically all BRICS nations, except for Russia, were former colonial subjugates of western states. Brazil was ruled by Portugal; India was administered by the British, Dutch and French in different phases; China saw oversight by numerous western states as well as Japan, while South Africa was under the authority of the Dutch and British (Porter, 1994). As such, the GDP, export and industrialisation levels of some BRICS nations are lower than some states associated with the global North (Nayyar, 2016). This economic disparity emerged partially due to what Rodney (1981) describes as the underdevelopment of former colonial states and the persistent challenge of these nations, acutely evident in Africa, to develop economies which diverge from colonial power relations. As these nations gained political independence in the post-colonial phase, there have been consistent attempts to implement educational governance and knowledge production, which contributes to national growth. Theorising this attempt, Bhorat, Cassim and Tseng (2016) suggest that quality provision of tertiary level knowledge to a nation's inhabitants fulfils the function of investing in its human capital. The question remains: which analytical frameworks may scholars and agents of the BRICS collective employ to develop new understandings of national attempts to increase necessary epistemic access to their inhabitants? This study applies and proposes Archer's (1995) 
social realist ontology as an effective framework for analysing the historical emergence of BRICS higher educational governance strategies and the efficacy in this phenomenon. It begins with a description of social realism as a methodological tool for analysis of the countries of BRICS. Following this, it maps governance challenges with respect to higher education faced by the countries of BRICS.

\section{Social Realism as a Methodological Tool for BRICS Analyses}

Social realist theory developed by Archer (1995) is an ontological framework. Ontology is a philosophical branch which probes human conceptions of what reality entails or what it means to exist (Eybers, 2018). Whereas constructivist ontologies conceive of reality as originating or emerging from the human mind, realist ontologies view existence as consisting of entities which live independently of our cognition (Imran, 2006; Vehmas \& Makela, 2008). That is, there is a real and tangible world with its own entities and powers, which exist without our perception of them as humans. This study applies a social realist ontology and executes an Archerian (Archer, 1995) framework which views social structures, human culture and agency as real existing phenomena. What is asserted here is that while they are invisible phenomena, these three entities have real powers which shape human experiences, including those related to educational governance. In order to effectively analyse and comprehend human experiences or social organisation as in the example of BRICS nations, Archer (1995) claims that it is necessary to identify the separate powers of and the interplay between social structures, culture and human agency. This theoretical approach is known as analytical dualism (Willmott, 1999). Examples of each of these ontological strata are illustrated in Table 1. When applying realist concepts to BRICS governance, examples of social structures include governments and ministries; culture signifies governmentality, subjectivities and ideologies (Amos, 2010). Agency incorporates actors who are policy designers, implementers or policy recipients in BRICS nations. Examples of this interplay is illustrated in Table 1.

\section{Table 1: BRICS Related Social Structures, Culture and Agency}

\begin{tabular}{l|l}
\hline Domain & Examples \\
\hline Social structures & $\begin{array}{l}\text { BRICS states, ministries of BRICS, New Development Bank, African Union, Asia } \\
\text { Cooperation Dialogue, Russian International Affairs Council, United Nations }\end{array}$ \\
\hline Culture & Language, national ethnicities, historical legacies, national laws \\
\hline Agency & BRICS citizens, policy makers, ambassadors and administrators \\
\multicolumn{2}{l}{ Source: Author, 2019}
\end{tabular}

When scholars and policy developers apply analytical dualism to interrogate and develop understandings of the powers and activities of higher education, governance structures, agents and governmentalities, theoretically these must be separated (Bhaskar, 1997; Willmott, 1999). Such conceptual distinction is expressed by Archer (1995, p. 15) as follows: "[t]he people in society and the parts of society [structures] are not different aspects of the same things". Alternatively, BRICS agents and structures possess their own unique powers. Even though BRICS is one geopolitical formation, structurally it is composed of multiple states, their agents and the governmentalities these entities bring to
BRICS deliberations (Amos, 2010). Governmentalities, in this context, denotes the ways powerful agents rule and steer higher education systems (Amos, 2010). In a social realist ontology, it is methodically erroneous to conflate the powers of structure, culture and agency as if ontologically they are not distinct. Archer's (1995) concern regarding analytical conflation is that it blurs the unique tendencies and powers of structures, culture and agency and constrains the capacity of scholars to illustrate how they interact with or repel each other in various configurations. When structures, culture and agency interplay in a manner which produces desired outcomes, we 
observe morphogenesis or, the emergence of new human experiences (Archer, 1995). However, when structures, culture and agency interplay in a manner which constrains desired outcomes or experiences, we undergo morphostasis (Archer, 1995). In this vein, when BRICS structures and agents effectively implement its policies, goals and development strategies, morphogenesis occurs. On the contrary, when goals are not reached through structural and agential interventions, and problems such as poverty or illiteracy persist, we experience morphostasis. In the next section, I map the challenges faced by BRICS.

\section{Mapping BRICS Challenges in a Social Realist Ontology}

BRICS scholars who are interested in the relationship between educational governance and multiple BRICS initiatives such as poverty reduction or employment creation may benefit from applying a realist analytical framework. This is due to the reality that while BRICS have shared goals, the diversity between the nations in terms of economic, social, educational and cultural challenges, is notable. As India finds its GDP in the second most influential position after China, with a growing population of well over a billion people, in 2013 roughly 250 million Indian inhabitants lived in extreme poverty (Newhouse \& Vyas, 2019). This is almost five times the amount of people living in South Africa, possessor of the smallest GDP out of the BRICS group. Brazil's GDP features in the third strongest position, however, it too, is experiencing challenges related to its financially constrained populace. Between 1997 and 2013, Brazil experienced a decline in its poverty rates (Worldbank.org, 2019). However, since 2014 the poverty rates of Brazil too have witnessed significant increases. By 2018 Brazil's number of poor and hungry people had tangibly increased (Phillips, 2018). As Douglas (2018, p. 1) reports "almost 55 million Brazilians were living in poverty in 2017 [which is] an increase of two million on 2016". Russia's and South Africa's GDP levels constitute the two bottom tiers of GDP in the BRICS block. However, their economies and economic histories reveal differences. Russia is an economically developed nation, while South Africa only recently attained democratic governance. Unlike Russia, which benefits from its economic integration with the global North, South Africa as a developing nation is struggling to increase its GDP and reduce societal inequalities (Redl, 2018). Poverty, unemployment and stagnant economic growth emerge in nations due to multiple variables, of which national histories are one. However, by highlighting the powers of social structures, culture and agency, a social realist ontology can assist scholars from multiple disciplines in the BRICS domain by methodologically identifying enabling and constraining variables in developmental initiatives; including governance of higher education systems. South Africa, with the smallest and slowest developing economy, has much to learn from the strategies of BRIC; simultaneously, there are principles, policies and practices in the South African domain, related to educational governance, which are of equal value to her BRIC partners. Methods of mapping these mutually beneficial principles and practices in a social realist ontology follow.

\section{Higher Education Governance in BRICS}

Drawing on Amos's (2010) conception, governance of higher education systems includes strategic mechanisms, policies and allocation of human and financial resources towards a nation's pedagogic goals. Mapping experiences of the governance of higher education systems in BRICS nations is illustratable in a realist ontology. Figure 1 highlights how, due to the interplay and powers of social structures, culture and agency, experiences of educational governance emerge and may be analytically framed by the scholarly community and BRICS actors. As it is impossible to exhaust analysis of all domains under educational governance in a study of this nature, what it is mainly concerned with is the provision of tertiary level education by BRICS nations to its populaces. Fataar (2003) reasons that policies which governments implement to facilitate educational systems are outcomes of the interests of civil society, the state itself, globalisation and market forces; these are structural entities. The suggestion is that from 
the general populace to industries, all sectors have an interest in the production of higher education knowledge. Fataar (2003) is not isolated in advocating the perspective that a nation which develops and implements findings of scientific knowledge may stimulate economic growth. Kumar, Stauvermann and Patel (2016), in testing possible correlations between high research output and economic growth in China and the United States claim that, indeed, such a correlation exists. They, too, suggest that nations which purposefully apply knowledge or technological innovations emerging from higher education research are posed to be innovators and leaders in various industries (Kumar et al.,
2016). Higher education implementation through educational governance may, therefore, be viewed as being integral to the needs of citizens, governments, local and global markets. This ideology challenges the notion that knowledge exists solely for knowledge's sake. As Nabudere (2006) asserts, history includes ample examples in which the application or withholding of knowledge via forms of governance occurred to manipulate natural and human resources. As highlighted by Kumar et al. (2016), the United States can simultaneously claim to possess the most developed economy and knowledge generation industries (Kumar et al., 2016).

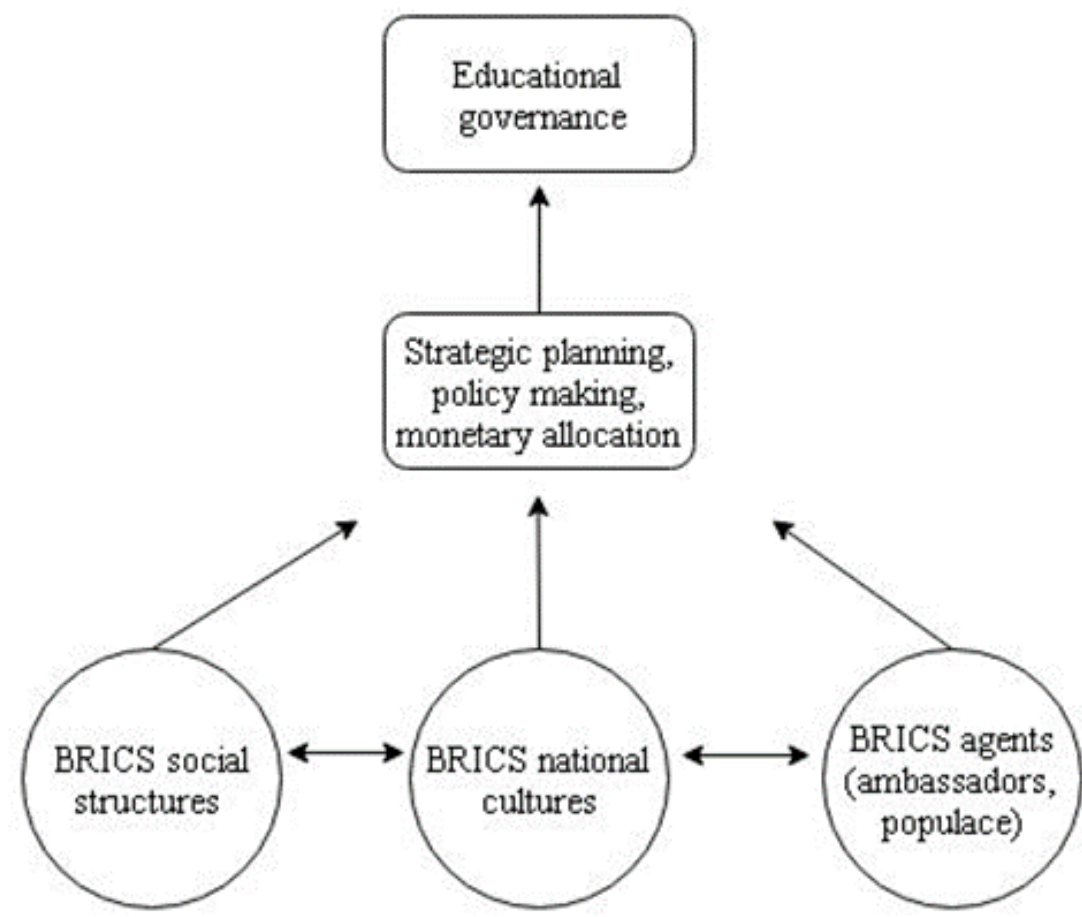

Figure 1:Social Realist Ontology of Educational Governance Source: Created by the Author

If researchers adopt the outlook that measurements of a nation's provision of higher education to its populace are an indication of its governmentality and commitment towards improving their quality of life, then comparative data related to contemporary BRICS strategies in this sphere may indicate why those nations with stronger economies excel while South Africa, occupying the bottom GDP tier, could also analyse why in its young democracy it has not achieved higher economic growth. Table 2 highlights the number of higher education institutions in BRICS nations and the ratio of institutions to population rate. This data indicates that nations with a history of establishing higher education institutions and government policies which value knowledge generation also evidence the highest GDP levels. Such is the case of BRICS states China and India as well as the pre-eminent example of non-BRICS member the United States. Data reveals that BRICS states with more substantial and larger GDP's than South Africa also evidence tertiary provision rates which are not far behind the 
United States. South Africa, contrarily, evidences a much smaller GDP when analysed alongside other BRICS nations. In addition, the quantity of South Africa's higher education provision to its populace is lowest on the ladder in the BRICS formation. Whereas China's university to population ratio is higher than both Brazil and India, the data indicates that its GDP rate remains high while its extreme poverty bracket is low. One of the key implications of the above data for BRICS scholars and agents is that the reduction of poverty requires simultaneous knowledge generation and economic stimulation. Institutions of higher learning have a critical role to play in this development strategy. Currently, South Africa is constrained in both domains, and this is made explicit via its high unemployment rates (Ismail \& Kollamparambil, 2015).

\begin{tabular}{|c|c|c|c|c|c|}
\hline BRICS state & $\begin{array}{l}\text { Number of } \\
\text { higher } \\
\text { education } \\
\text { institutions }\end{array}$ & $\begin{array}{l}2019 \\
\text { population } \\
\text { count }\end{array}$ & $\begin{array}{l}\text { University to } \\
\text { population } \\
\text { ration }\end{array}$ & GDP (2017) & $\begin{array}{l}\text { \% population } \\
\text { living in extreme } \\
\text { poverty }\end{array}$ \\
\hline China & 2,914 & $1,420,574,479$ & 1: 487,499 & $\begin{array}{l}12,24 \\
\text { Trillion }\end{array}$ & 1.4 \\
\hline India & 49,536 & $1,370,339,445$ & $1: 27,663$ & $\begin{array}{l}2,597 \\
\text { Trillion }\end{array}$ & 21.2 \\
\hline Brazil & 2448 & $212,507,996$ & $1: 86,808$ & $\begin{array}{l}2,056 \\
\text { Trillion }\end{array}$ & 3.4 \\
\hline Russia & 3000 & $143,887,764$ & $1: 47,962$ & $\begin{array}{l}1,578 \\
\text { Trillion }\end{array}$ & 0 \\
\hline South Africa & 61 & $59,000,000$ & 1: 967,213 & 349,4 Billion & 18.9 \\
\hline $\begin{array}{l}\text { United } \\
\text { States }\end{array}$ & 4,360 & $325,700,000$ & 1: 74,701 & $\begin{array}{l}19,39 \\
\text { Trillion }\end{array}$ & ----- \\
\hline
\end{tabular}

\section{Real Mechanisms and BRICS Governance of Higher Education}

While the effectiveness of a nation's governance of higher education systems may quantitatively be scrutinised through considering GDP's, ratios of availability of tertiary institutions to populaces and poverty rates; BRICS scholars and agents require a methodological framework to enable identification of those pedagogic mechanisms, which either enable economic growth or constrain it. Undoubtedly statistical knowledge is indispensable to strategic planning in BRICS higher education governance systems. However, due to the realist methodology of identifying the powers and activities of mechanisms which produce such data, it is critical to interrogate the interplay of structures, culture and agency in decision and policymaking as these events tangibly affect the wellbeing of
BRICS inhabitants. The question remains: why is South Africa's provision of higher education knowledge to its inhabitants, as emerging from its governance strategies and when contrasted with its BRICS partners, significantly lower? Table 2 paints the disparity of such provision between South Africa and her BRIC partners.

\section{History, Culture and Contemporary BRICS Higher Education}

Before European nations colonised southern Africa, the original inhabitants, known as the Khoisan people, possessed an oral society and culture (Chebanne, 2010). The epistemic traditions of Khoisan communities, including how members were acculturated to ways of engaging with the natural environment as well as of perpetuating community traditions were transmitted through oral modes (Guenther, 1989). Orality in the context of this study is not 
approached as a technical mechanism which is less sophisticated than written modes of communication (Ong, 1991). Scholars such as Bandia (2015) highlight how translations of oral expositions are rich repositories of the histories, epistemologies and traditions of communities. By drawing on these conceptions, this study conceptualises orality as a cultural and linguistic tool which African and other pre-colonial era communities applied to communicate and share culture. While more northern regions of Africa including ancient Kemet, Ethiopia or Timbuktu record examples of pre-colonial written epistemic traditions, early South Africans, except for their artwork employed verbal communication in multiple forms, including songs and proses (Ezzamel \& Hoskin, 2002; Lliteras, 2013; Crummey, 2006; Wadley, 1996). It should be noted that scholarship exists which approaches artistic drawing as a literacy mode (Riefstahl \& Davies, 1959). While the aim of this study is not to elaborate on precolonial modes of knowledge generation, it should be observed that South Africa's current, post-apartheid system of educational governance and modes of teaching and learning are predominantly from the West; they are not embedded in the epistemic traditions and practices of Africa. Kallaway (2005) acknowledges that South Africa and Africa inherited western epistemic systems which replaced their own modes of teaching community members and maintaining necessary systems of social organisation.

India and China, like regions in northern Africa (Kemet and Ethiopia), possess long histories of formal instruction which include written modes of communication. This history and written epistemic orientation diverge from South Africa's history of orality. China's Peking University which was established in 1898 is ranked number twenty-four out of the world's top institutions and is number five in Asia (Times Higher Education, 2020). As China's Confucianist cultural values are embedded in its written tradition of educating humans, the emergence of its higher education system of governance was able to draw on centuries of written Confucianist practices (Thomas, 1993; Ooms \& Makoto, 1994). Comparatively, this written foundation for higher education development in China diverges from the emergence of South Africa's systems of higher educational governance. Whereas China's modern system drew on its Confucianist and history of written epistemologies, modern South Africans, especially the black majority enter the system from a unique historical context. They only entered and experienced modern governance systems of higher education after hundreds of years of colonialism and then apartheid. Even when modern universities emerged in South Africa, they were designed to enable the western inherited economy and those Europeans who implemented it. South Africa was further racially divided by the apartheid government and this governmentality manifested in its policies of marginalising the African majority. There is evidence to suggest that the origins of South Africa's current higher educational system accentuates divisions according to "race". Menon's (2015, p. 173) study of educational governance in South Africa reveals how during the apartheid era, there were nineteen institutions of higher learning for white South Africans who constituted less than $10 \%$ of the population. However, for the African majority there were thirteen; these institutions were of an inferior quality and some are still struggling to overcome legacies of being underresourced.

India like China also emerges from an ancient tradition of applying indigenous written modes of communication for sharing epistemic knowledge and traditions of its cultural communities. Some of India's writing systems emerge from Perso-Arabic origins while others are rooted in that nation's Brahmin traditions (Mudur, Nayak, Shanbhag, \& Joshi, 1999). India's modern systems of educational governance, mirroring China's, emerged from indigenous and written traditions which preceded the colonial age. Brazil's history of higher education reflects that of South Africa in that their first formal universities were implemented by colonial authorities (McCoy, 1959). As asserted above, Brazil's indigenous populations employed oral traditions. The Marajoara people who lived at the mouth of the Amazon River between the 5th 
and 16th Centuries engaged in complex pottery with intricate patterns evidencing picture writing (Calza et al., 2007; Riefstahl \& Davies, 1959). Unlike China and India but sharing historical experiences with South Africa, indigenous Brazilians did not possess a written system of communication which was transmitted into modern institutions of higher learning. Russia's higher education characteristics are unique in that it bears commonalities with Europe. Russia's oldest institution of higher learning, the Slavic-GreekLatin Academy, originated in 1687 (Smirnov, 2015). Russia also adheres to the Bologna Process, a standard and quality assurance mechanism of European nations. The aim of this collective is to highlight the "central role of universities in the development of European cultural values; the need to adjust education to social demands [and the] mobility of citizens to facilitate their access to educational centres" (Shchelkunov, 2014, p. 44). As a partaker in this process, it is evident that Russia shares cultural values with the European system of higher education governance. The significance of the cultural and epistemic histories of BRICS nations is that their higher education governance strategies originate in diverse contexts. Perhaps one of the most significant factors relates to the application of written or oral epistemic practices in the pre-tertiary phase. The efficacy of BRICS culture and history in the development of the higher educational systems is illustrated in Figure 2.

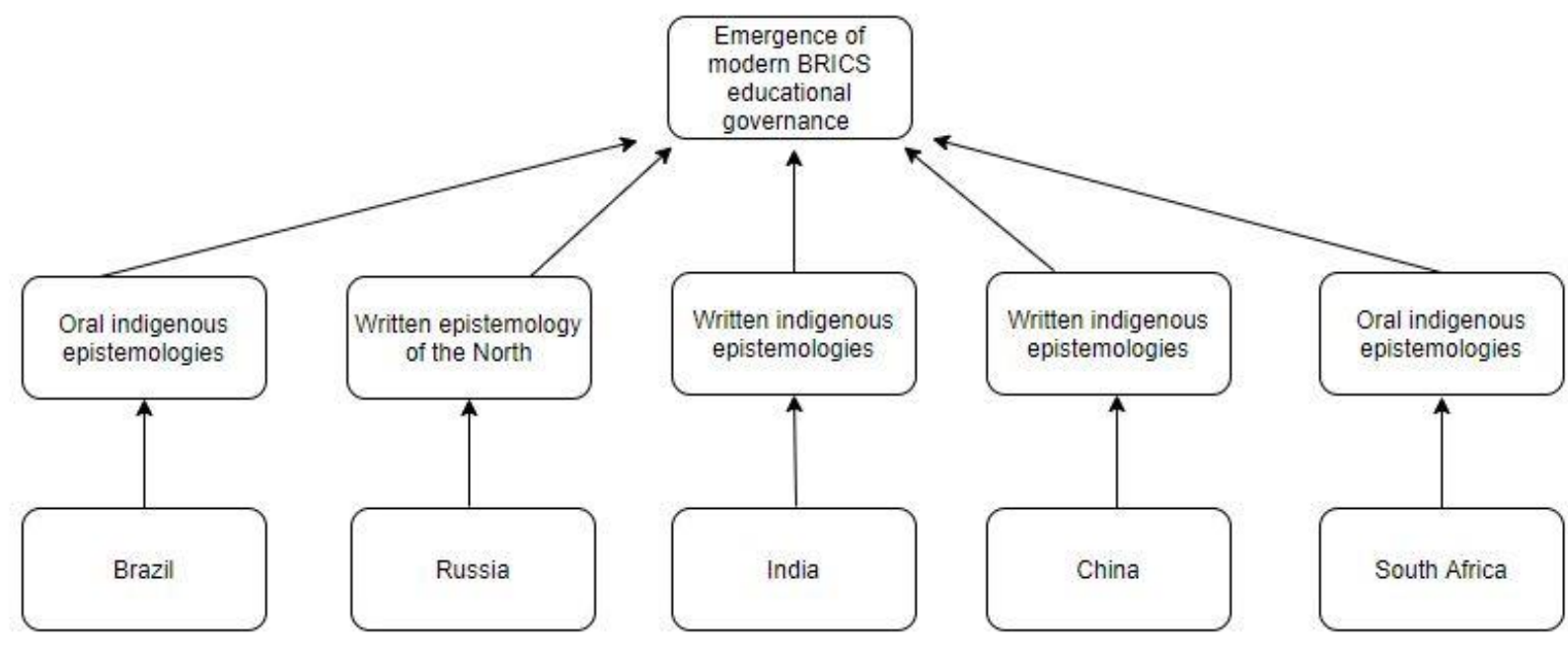

Figure 2: Emergence of BRICS Epistemologies Source: Created by the Author

The intention of highlighting the interplay of the epistemic traditions and histories of BRICS nations and the emergence of their contemporary educational systems of governance is not undertaken to be reductionist. I am not arguing for analyses that attempt to reduce our understandings of educational governance systems as products of history and epistemology. Rather, I advocate a deductivist analysis, which acknowledges that our current experiences of higher educational governance, whether of policies, their manifestation in practice or of the agency of key actors, may be deduced to key theoretical concepts namely, social structures, culture and agency (Archer,
1995, p. 16). According to realist analyses, these entities are also generative mechanisms that possess powers to produce social events and, in turn, human experiences of them. Within this context, experiences of educational governance are deducible to the powers of social structures, culture, and agency. While history, which was discussed above, is a broad approach to understanding the present, our epistemic traditions and practices may specifically be identified as belonging in the realist domain of culture. As such, culture as a real mechanism possesses powers, along with agency and social structures, to generate experiences of 
educational governance. Our governmentalities emerge due to our cultural orientations.

\section{Discussion}

While the quantitative data shared is significant in that it may aid actors and scholars of BRICS to analyse the phenomenon of higher education governance from a comparative angle; the central aim of this study was to highlight to the reader how the interplay of social structures, culture and agency can generate social events and human experiences of them. This includes human experiences of the governance and governmentalities of higher education. As asserted above and within a social realist ontological framework, the geographical, historical, and cultural characteristics of BRICS nations feed into aspects of our governmentality. Key experiences of higher educational governance, which a social realist ontology can highlight and interrogate include, but are not restricted to, supply and demand of educational provision, influences of governmentality and adoption of best practices by inter-BRICS comparison and possible collaboration in the development of our systems. A social realist ontology directs researchers to critically consider the enabling and constraining powers of the agency which administrators, curriculum designers, teachers, researchers, students, and inhabitants of BRICS have over our higher education systems of governance. A social realist ontology also enhances our understandings of the powers of social structures in higher education governance. Examples of these social structures include BRICS nations, their ministries of education, universities, and civil society formations which have a stake in educational governance. These structures, like agency and culture, possess powers (Archer, 1995, p. 51) to either expand and develop a nation's higher education system or not to use these powers for these purposes. Social structures rely on the agency of human beings who make vital decisions to activate their powers. In this vein, BRICS actors, ministers of higher education, university presidents, scholars, and students all, in varying degrees, possess powers within their respective domains (structures) to shape the education system by exercising their agency. Each of these agents is, however, also constrained by the structural and cultural conditions in their nations and universities. Culture, at the level of nations, ethnic groups, institutions, and individuals is the social adhesive that binds people together but may also separate them in epistemic strategies. Each BRICS nation possesses a unique history and culture of developing knowledge among its inhabitants through systems of higher learning. However, as in the case of each BRICS nation, culture may also divide humans and therefore constrain the implementation of systems of governance which equally value all a nation's people.

While each of the BRICS nations has undergone educational governance trajectories that were shaped by their indigenous cultures, modes of communication, and interactions with other ethnic groups throughout their histories, there is much that each one can learn from the other. If analytically the number of institutions of higher learning provided to BRICS citizens is correlated with a nations' university to population ratio and poverty rates, South Africa, the member with the smallest economy and lowest university to populace ratio, stands to learn much. This is because, as evidenced in the pre-colonial or contemporary eras, China, India, and Russia's provision of higher learning to their populace demonstrates that nations benefit developmentally from populations with access to formal and written modes of education. Enabling access to expert and technical knowledge is necessary for contemporary nations to develop a populace that is sufficiently equipped with attributes required in an age of rapid globalisation and technological advancements. Wolhuter (2014, p. 275) asserts that "education has come to be understood in terms of national economic survival [as it] is commonly recognised that the [knowledge economy is overtaking the production] economy".

While South Africa's economy is the smallest, there are lessons emerging from it towards 
higher education governance for other BRICS nations. Perhaps the most critical lesson in this phase of its fledgling democracy is that the demand for education, especially by the youth, will not cease and is increasing. Recently South Africa experienced youth uprising for access to quality education under the \#FeesMustFall movement (Luescher, Loader, \& Mugume, 2017). In this intense and often violent series of national protest students expressed demands for access to higher education, linguistically inclusive curricula and decolonised knowledge (Luescher et al., 2017). While it appears the South African government and affected parties have temporarily quelled youth protests, possibly through increasing financial assistance for tertiary study, the ideological tensions remain. Persistent calls from students and scholars in South Africa decry what they perceive as the marginalisation of African epistemologies and instruction of indigenous African modes of organisation (Eybers, 2019; Mampane, Omidere \& Folake, 2018). There is a sense that while South Africa's higher education system is transforming, due to the urgent challenges of poverty and unemployment, which affect the youth, it is not changing at the required pace. BRICS nations would, therefore, benefit, by applying a social realist ontology in considering how the interplay of social structures, culture, and agency are generating policies and practices which consider the needs of the weakest of society. This requires critical consideration of principles of social justice and ubuntu, which is an African philosophy highlighting the humanness of all people, including all BRICS members (Rambiritch, 2018). If such principles may emerge in experiences of higher education governance, then possibly, those rich values from ancient Brazil, Russia, India, China, and South Africa, which are still active in local communities, may aid in creating hope for the youth and future experts. Future studies of BRICS higher educational governance that apply a social realist ontology should consider how trans-languaging strategies, a method of drawing on cultural principles embedded in indigenous languages while still applying mainstream vernaculars, may be incorporated into our curricula (Boakye, 2015). This is because our languages are amongst the riches of cultural sources, embodying the very identities of nations.

\section{Conclusion}

The concepts governance and governmentality are effective tools for scholars who aim to understand the relationships between the subjectivities of agents in our higher education systems. Social realist ontology through analytical dualism aids such interrogations, including in the BRICS domain, by enabling researchers to identify and distinguish between the powers of educational structures, cultures and influential actors. However, understanding of diverging achievements, provision of and access to higher education in BRICS nations also necessitates historical consideration of the epistemic and literary traditions of each nation. While some BRICS nations emerge from ancient, written educational and literary traditions such as India and China, South Africa evidences an epistemic tradition which was originally oral and then replaced by colonial and apartheid, educational modes of instruction. What is evident in the contemporary age and in the BRICS geopolitical formation is that nations with larger higher education systems also evidence larger GDP and technological innovation levels. South Africa has the lowest higher education to populace ratio. It also has the smallest economy. This is an untenable situation for the world's most unequal nation, and its leaders should consider enhancing higher education provision for all inhabitants, including immigrants and refugees.

\section{References}

Amos, K. (2010). Governance and governmentality: Relation and relevance of two prominent social scientific concepts for comparative education. Educacao e Pesquisa, 36(SUPPL. 1). doi:10.1590/S151797022010000400003

Archer, M. S. (1995). Realist social theory : the morphogenetic approach. Cambridge:

Cambridge University Press. https://doi.org/10.1017/CBO9780511557675 
Archer, M.S. (2020). The Morphogenetic Approach; Critical Realism's Explanatory Framework Approach. In P. Róna \& L. Zsolnai L (Eds.), Agency and Causal Explanation in Economics. Virtues and Economics (pp. 137150). Cham, Switzerland: Springer. doi:10.1007/978-3-030-26114-6

Besudo, H., Tok, E., \& Winters, K. (2013). South Africa in the BRICS Opportunities, Challenges and Prospects. Africa insight., 42(4), 1-15.

Bhaskar, R. (1997). A realist theory of science. London: Verso.

https://doi.org/10.4324/9780203090732

Bhorat, H., Cassim, A., \& Tseng, D. (2016). Higher education, employment and economic growth: Exploring the interactions.

Development Southern Africa, 33(3), 312-327. doi:10.1080/0376835X.2016.1161501

Boakye, N. (2015). The social dimension of reading literacy development in South Africa: Bridging inequalities among the various language groups. International Journal of the Sociology of Language, 2015(234), 133-156. doi:10.1515/ijsl-2015-0008

Calza, C., Anjos, M. J., Bueno, M. I. M. S., Lima, T. A., Lopes, R. T., th Topical Meeting on Industrial, R., \& Radioisotope Measurement Applications, I.-H. O. C. (2007). EDXRF analysis of Marajoara pubic covers. Nuclear Inst. and Methods in Physics Research, B, 263(1), 245248. doi:10.1016/j.nimb.2007.04.099

Chebanne, A. (2010). The Khoisan in Botswana Can multicultural discourses redeem them? Journal of Multicultural Discourses, 5(2), 87105. doi:10.1080/17447141003639801

Eybers, O. O. (2018). Friends or foes? A theoretical approach towards constructivism, realism and students' well-being via academic literacy practices. South African Journal of Higher Education, 32(6), 251-269. doi:10.20853/32-6-2998

Eybers, O. O. (2019). Applying Ayittey's Indigenous African Institutions to generate epistemic plurality in the curriculum.

Transformation in Higher Education, 4(0), e1-e6. Retrieved from doi:10.4102/the.v4i0.68
Ezzamel, M., \& Hoskin, K. (2002). Retheorizing accounting, writing and money with evidence from Mesopotamia and ancient Egypt. Critical Perspectives on Accounting, 13(3), 333-367. https://doi.org/10.1006/cpac.2001.0500

Douglas, B. (2018). Number of Brazilians Living in Poverty Rises 2 Million in a Year. Retrieved from https://www.bloomberg.com/news/articles/20 18-12-05/number-of-brazilians-living-inpoverty-rises-2-million-in-a-year

Fataar, A. (2003). Higher education policy discourse in South Africa : a struggle for alignment with macro development policy : perspectives on higher education. South African Journal of Higher Education, 17(2), 31-39. https://doi.org/10.4314/sajhe.v17i2.25295

Guenther, M. G. (1989). Bushman folktales: oral traditions of the Nharo of Botswana and the /Xam of the Cape. Stuttgart: F. Steiner Verlag Wiesbaden GMBH. https://doi.org/10.2307/1160128

Imran, A. Z. (2006). A framework and a methodology for developing authentic constructivist e-Learning environments. Journal of Educational Technology \& Society, 9(2), 198212.

Ismail, Z., \& Kollamparambil, U. (2015). Youth Unemployment Duration and Competing Exit States: What Hides Behind Long Spells of Black Youth Unemployment in South Africa? African Development Review, 27(3), 301-314. doi:10.1111/1467-8268.12150

Kumar, R. R., Stauvermann, P. J., \& Patel, A. (2016). Exploring the link between research and economic growth: an empirical study of China and USA. Quality \& Quantity : International Journal of Methodology, 50(3), 1073-1091. doi:10.1007/s11135-015-0191-3

Lo, V. I., Hiscock, M., \& Edward Elgar, P. (2014). The rise of the BRICS in the global political economy : changing paradigms? Cheltenham: Edward Elgar. https://doi.org/10.7202/1030136ar

Luescher, T., Loader, L., \& Mugume, T. (2017). \#FeesMustFall: An Internet-Age Student 
Movement in South Africa and the Case of the University of the Free State. Politikon, 44(2), 231-245. doi:10.1080/02589346.2016.1238644

Mampane, R., Omidire, F., \& Folake, R. (2018). Decolonising higher education in africa: Arriving at a glocal solution. South African Journal of Education, 38(4), 1-9.

doi:10.15700/saje.v38n4a1636

McCoy, D. B. (1959). Education in Brazil. Peabody Journal of Education, 37(1), 39-43.

Menon, K. (2015). Supply and Demand in South Africa. New York: Springer. https://doi.org/10.1007/978-94-017-9570-8_9

Mudur, S. P., Nayak, N., Shanbhag, S., \& Joshi, R. K. (1999). An architecture for the shaping of Indic texts. Computers \& Graphics, 23(1), 7-24. doi:10.1016/S0097-8493(98)00113-7

Nabudere, D. W. (2006). Towards an Afrokology of knowledge production and African regeneration. International Journal of African Renaissance Studies - Multi-, Inter- and Transdisciplinarity, 1(1), 7-32. doi:10.1080/18186870608529704

Nayyar, D. (2016). BRICS, developing countries and global governance. Third World Quarterly, 37(4), 575-591.

doi:10.1080/01436597.2015.1116365

Ooms, H., \& Makoto, K. (1994). Introduction to "the nature of early tokugawa confucianism" by kurozumi makoto. Journal of Japanese Studies, 20(2), 331-331. doi:10.2307/133197

Ong, W. J. (1991). Orality and literacy : the technologizing of the word. London: Routledge. https://doi.org/10.4324/9780203328064

Peking University: World University Rankings. (2020). Retrieved on 3 March 2020 from, https://www.timeshighereducation.com/worlduniversity-rankings/peking-university
Porter, A. N. (1994). European imperialism, 1860-1914. Houndmills, Basingstoke, Hampshire: Macmillan.

https://doi.org/10.1007/978-1-349-10544-1

Rambiritch, A. (2018). A social justice approach to providing academic writing support.

Educational Research for Social Change, 7, 46-

50. https://doi.org/10.17159/2221-

4070/2018/v7i1a4

Riefstahl, E., \& Davies, N. M. (1959). Picture Writing in Ancient Egypt. American Journal of Archaeology, 63(1), 89. doi:10.2307/502116

Rodney, W., Babu, A. M., \& Harding, V. (1981). How Europe underdeveloped Africa (Rev. pbk. ed. ed.). Washington, D.C.: Howard University Press. https://doi.org/10.2307/20048265

Shchelkunov, M. D. (2014). The Bologna Process. Value Inquiry Book Series, 276.

Smirnov, S. (2015). History of the moscow slavic-greek-latin academy. Norderstedt, Germany: Book on Demand Ltd.

Thomas, H. C. L. (1993). Book Review: Confucianism and Family Rituals in Imperial China: A Social History of Writing about Rituals. The Journal of Asian Studies, 52(3), 708-710.

Vehmas, S., \& Mäkelä, P. (2008). A realist account of the ontology of impairment. Journal of Medical Ethics, 34(2), 93-95.

doi:10.1136/jme.2006.019042

Willmott, R. (1999). Structure, Agency and the Sociology of Education: Rescuing Analytical Dualism. British Journal of Sociology of Education, 20(1), 5-21. https://doi.org/10.1080/01425699995461

Wolhuter, C. C. (2014). Research on HE in South Africa: stocktaking and assessment from international comparative perspectives. South African Journal of Higher Education, 28(1), 275291. https://doi.org/10.20853/28-1-323 